\title{
Diaspora Politikalarına Yönelik Çağdaş Kuramsal Yaklaşımlar ve Türk Diaspora Politikası ${ }^{1}$
}

\author{
DOI: 10.26466/opus.747426 \\ * \\ Esra Sağlam * \\ * Dr., Blim, Sanayi ve Teknoloji Bakanlığı/TÜBITAK, Ankara/Türkiye \\ E-Posta: esrasaglam1@yandex.com \\ ORCID: 0000-0002-5633-5366
}

Öz

Küreselleşme, kapitalizm ve demokrasi alanındaki gelişmelerin diaspora kavramının anlamında yarattığı dönüşüm ve göç veren ülkelerin siyasi, ekonomik ve kültürel enstrümanlar olarak diaspora gruplarını keşfi ile şekillenen ve dünyada gittikçe yaygınlık kazanan diaspora politikaları, 2000'li yıllar sonrası Türkiye'nin de önem verdiği politika alanlarından biri haline gelmiştir. Özellikle ilk kez 2002 yılında iktidar olan AK Parti yönetimi sonrası, siyasi retorikte diaspora kavraminın siklikla kullanılmaya başlandı̆̆̆ yeni diaspora kurum ve enstrümanlarının ihdas edildiğ i ve"yumuşak güç" kullanımına izin veren kamu diplomasisi araçlarının devreye sokulduğu görülmektedir. Bu çalışmanın amacı, diaspora yönetimi konusunda esen küresel rüzgara uyum să̆ladığ̆ anlaşılan son dönem Türk diaspora politikasını, alanyazında öne çıkan çağdaş kuram ve yaklaşımlar açısından ele almaktır. Bu amaçla, ilk olarak diaspora kavramının geçirdiği dönüşüm ve güncel çağrışımları, köken ülke ve diaspora arasındaki ilişkiler ve devletlerin diaspora politikaları yürütme noktasındaki motivasyonlar konularında öne çıkan kuramsal yaklaşımlar incelenmiş ve sonrasında söz konusu kuramların Türk diaspora politikasını açıklama noktasında sundukları imkânlar tartışılmıştır.

Anahtar Kelimeler: Diaspora, diaspora yönetimi, Türk diaspora politikası, köken-ülke, diaspora politikalarmin motivasyonlar

\footnotetext{
${ }^{1}$ Bu makale Esra Sağlam'ın "Türkiyeli Göçmenlerin Gözünden Türk Diaspora Politikası. Toplumsal Sorunlar ve Beklentiler: Avusturya Örneği" isimli doktora tezinden türetilmisțir
} 


\title{
Contemporary Theoretical Approaches to Diaspora Policies and Turkish Diaspora Policy
}

\begin{abstract}
Having gained popularity around the world, diaspora policies, which have been shaped by the transformation of the diaspora concept with developments in globalization, capitalism and democracy, and the recognition of diaspora groups in the eyes of the home countries as political, economic and cultural instruments, have become one of the leading policy fields in Turkey since the 2000s. With the administration of the AK Party that came to power in 2002, the diaspora concept has come to be frequently used in political rhetoric, new diaspora institutions and instruments have been created, and public diplomacy instruments that allow using soft power have been entered into practice. The present study analyzes recent Turkish diaspora policies, which seem to have adapted to the global changes witnessed in diaspora management, in accordance with the most prominent modern theories in literature. To this end, first, the theoretical approaches to the diaspora concept, its transformation and current connotations, the relations between the country of origin and the diaspora, and the motivations of states in enacting diaspora policies are examined, after which the opportunities offered by such theories to explaining Turkey's recent diaspora policies are discussed.
\end{abstract}

Keywords: Diaspora, diaspora management, Turkish diaspora policy, origin-country, motivations of diaspora policies 


\section{Giriş}

Sosyal bilimlerdeki bir çok kavram gibi, anlamı üzerinde uzlaşı sağlanabilmiş bir kavram olmaktan uzak görünse de, diaspora kavramı genel itibariyle coğrafi dağılma ve bu dağılmaya eşlik eden kimliklerin, kültürlerin ve toplumsal ilişkilerin mekânsal dağılım durumunu ifade etmek için kullanılmaktadır (Hall, 1998).

Etimolojik olarak yunanca diasperien; dia- "boyunca, karşıda" ve speriensperio "yayılmak, tohum saçmak" kelimelerinden türemiş olan (Braziel ve Mannur, 2003, s.1) kavramın göç ve kolonizasyonu karşılayan ve nötr çağn1şımlar uyandıran ilk versiyonu, M.Ö. 6. Yüzyılda Babil Krallığı tarafından Kudüs'ten farklı coğrafyalara dağıtılan Yahudilere atıfta bulunulmasıyla beraber yeni bir semantik anlam kazanmış ve anavatanını kaybetmiş ve etnik şiddete maruz kalmış şahıslar ve topluluklar için kullanılan bir kavrama dönüşmüştür (Tötölyan, 1996, s.12). İlk kez 1931 yılında Dubnov, kavramı Yahudi halkının tarihsel deneyiminden ayırır ve kendi vatanından ayrılarak dağılan tüm nüfusları tanımlamak için kullanır. Terimin anlam sahasını genişleten bu eğilim, giderek artmış ve 1990 'l ly yllardan itibaren diaspora teriminin kullanımındaki çeşitlilik ve işaret ettiği gruplarının enflasyonu doruk noktasına ulaşmıştır (Dufoix, 2011, s.26-27).

Bu süreçte, diaspora kavramını tanımlamak üzere çeşitli yaklaşım ve kuramlar dile getirilmiştir. Temel olarak ikiye ayırabileceğimiz bu yaklaşımların ilki, tarihi Yahudi sürgünü deneyiminden yola çıkılarak tanımlandığı anlaşılan klasik diaspora yaklaşımıdır. Travmatik unsurların bulunduğu zorunlu bir dağılma durumuna, sürekli olarak terkedilen anavatana geri dönüş mitine ve ortak bir kimlik bilincinin varlığına dayanan bu tanım (Safran, 1991, s.83-84), diasporayı anavatana dönüş temelinde, homojen, sabit ve değişmez bir kategori olarak resmetmesi nedeniyle eleştiri konusu olmuş ve bu yaklaşımın modern deneyimleri tanımlamakta yetersiz kaldığı ifade edilmiştir (Kaya, 2000, s.61).

Kısıtlı bir çerçeve sunan bu yaklaşım karşısında Cohen (1997), zorunlu ve travmatik olmasına gerek olmadan çeşitli amaçlarla anavatandan kendi isteğiyle ayrılan toplumları da diaspora içerisinde tanımlamıştır. Çağdaş diaspora yaklaşımına kapı aralayan bu tanım sonrası, diaspora kavramı hizmet, ticaret ve kültürel nedenler başta olmak üzere çeşitli sebeplerle muhtelif ülkelere dağılan bütün göçmenler için kullanılmaya başlanmıştır. 
Günümüzde diaspora kavramına ilişkin yaklaşımlar, ulus-aşırı alanların varlığını daha belirgin ve meşru hale getiren küreselleşme, temel hak ve özgürlüklere ilişkin vurgunun artması (Kurubaş, 2006, s.97) gibi bazı temel değişimlerin etkisiyle yeni bir şekil almıştır. Çağdaş diaspora yaklaşımlarına etki eten bir diğer gelişme ise, diasporik kimliklerde melezlik ve merkezsizliğe vurgu yapan postmodernizm ve ulus-aşırılık (transnationalism) kuramlarının (Glick Schiller, Basch, Szanton Blanc,1992) alanyazında güç kazanmasıdır. Stuart Hall, Paul Gilroy ve James Clifford'un başını çektiği bu yaklaşıma göre, diaspora grupları bir ulus-devlet ve etnik bir kimliğe dayanmayan, çok kimlikli ve heterojen topluluklardır (Dufoix, 2011, s.33). Tüm bunların yanında alanyazında, diaspora kavramına ilişkin yapısalcı yaklaşımın da öne çktığı görülmektedir. Özcü yaklaşıma tepki olarak, diaspora gruplarının kendiliğinden oluşan sosyal aktörler olmadığını ve siyasi olguların sonuçları olduğunu savunan bu yaklaşıma göre, diasporalar bazı elitlerin siyasi projeleri ve çıarları doğrultusunda, bir kimlik ve bellek yaratılarak oluşturulmaktadır (Bauböck ve Faist, 2010, s.313-316).

Bu açıklamalar dikkate alındığında çağdaş diaspora tanımı; gönüllü ve zorunlu tüm uluslararası göç şekillerini imlemekte ve diasporalar sosyal pratiklerinde ve kararlarında tek bir sosyal aidiyetle sınırlı kalmayan, çok-ülkeli ve melez gruplar olarak kabul görmektedir.

Uluslararası alanyazına bakıldığında; gerek diaspora kavramı gerekse devletlerin diasporalarıyla ilişkileri konularında önemli bir literatür olgunluğa erişildiği görülebilmektedir. Türkiye'de ise konunun önemiyle kıyaslandığında, bir devlet politikası olarak Türk Diaspora Politikası alanında yapılan çalışmaların akademik bir doygunluğa ulaşamadığı anlaşılmaktadır. Öte yandan, Türkçe literatürde göç ve diaspora çalışmaları yürütülürken çoğunlukla aynı kuramsal yaklaşımlardan; yani göç teorilerinden yararlanıldığı görülmektedir. Konuya göçmenler ve göç alan ülke bağlamında yaklaşırken oldukça elverişli bir bağlam sunan ve göçün sebepleri ve gelişimini anlamaya yardımcı olan göç teorilerinin, diaspora politikaları söz konusu olduğunda sunduğu imkânlar oldukça kısıtlıdır. Diaspora politikalarının ortaya çıkışı ve gelişimini, ülkeleri bu politikalara iten sebepleri anlayabilmek için farklı bir kuramsal yaklaşım gereklidir. Bu kapsamda, bu çalışma Türkçe literatürde diaspora politikası teorilerine yaslanarak Türk diaspora politikasını ele alan bir araştırma olması hasebiyle özgünlük kazanmaktadır. Çalışmada bu kap- 
samda, alanyazında konuya ilişkin öne çıkan birincil ve ikincil kaynaklar analiz edilmiş ve mevcut kuramsal yaklaşımların Türk Diaspora Politikasını açıklama noktasında sundukları katkılar anlaşılmaya çalışılmıştır.

\section{Diaspora Politikalarının Dönüşümü ve Bu Politikalara Yönelik Kuramsal Yaklaşımlar}

Yukarıda bahsedildiği üzere, klasik kavramsallaştırmanın ezici ağırlığından kurtulan ve travmatik unsurlarından arındırılan diaspora kavramı artık dünyada olumlu çağrışımlarla anılmaktadır. Bir zamanlar 'kurbanlar' olarak görülen diasporalar artık diaspora kongreleri gibi etkinliklerde 'ulusal kahramanlar' olarak takdim edilen, çoklu-kültür ve aidiyete sahip bireyler olarak ülkeler arası ilişkilerde ve anavatana sundukları katkı nedeniyle alkışlanan toplulukları ifade etmektedir (Gamlen, Cummings, Vaaler, Rossouw, 2013, s.4). Diaspora kavramının olumluya evrilen bu çağrışımları, diaspora gruplarının ülkeler nezdinde siyasi, ekonomik ve kültürel enstrümanlar olarak keşfedilmesi ve küreselleşme ve demokrasinin insanlığı zorladığı yer itibariyle karşımıza çıkan bu olumlu tablo, dünya ölçeğinde devletler nezdinde diasporaya yönelik ilgideki artışı açıklamamıza da yardımcı olmaktadır.

Literatürde "diasporanın dönüşümü" (diaspora turn) (Agunias, 2009) olarak isimlendirilen bu durum sonucunda, dünyada giderek daha fazla ülke ve uluslararası organizasyon yurtdışındaki topluluklarla işbirliği geliştirme ve bağ kurma amaciyla politikalar geliştirmektedir (diaspora engagement policy). Bunun en belirgin göstergesi, özellikle son on yılda devletler bünyesinde kurulan diaspora kurumlarının sayısındaki artıştır. Migration Policy Institut 2012' de yayınladığı "A Handbook for Policymakers and Practitioners in Home and Host Countries" isimli çalışmada dünyada diaspora ile ilgilenen kurum sayısın 56 ülkede 400 kurum olarak vermektedir. Bunlardan 26 tanesi bakanlık düzeyinde ve 12 tanesi ise sadece diasporaya ayrılmış bakanliklardır (Agunias, ve Newland., 2012, s.72).

Bunun yanında, diaspora yönetimi uluslararası kuruluşlar, çoklu platformlar ve araştırma kuruluşları tarafından da tavsiye raporları ve çeşitli yayınlar yoluyla teşvik edilip gündem maddesi haline getirilmektedir. Diasporalar ile kurulacak ilişkinin, Dünya Bankası (Kuznetsov ve Sabel, 2006), Uluslararası Göç Organizasyonu (International Organisation of Migration, 2013) 
ve Amerika Uluslararası Kalkınma Ajansı (The United States Agency for International Development, 2013) gibi güçlü uluslararası kuruluşlar tarafından da teşvik edilmekte olduğu görülmektedir.

Diaspora politikalarındaki ikinci temel dönüşüm ise, topraktan kopuk bir vatandaşlık anlayışının yükselişi ve bu bakış açısının devletler tarafından geliştirilen diaspora politikalarında öne çıarılmasıdır. Artık bir ülkenin insanı olmak sadece o ülkede yaşamak anlamına gelmemektedir. Bu bağlamda, göç veren ülkelerin diasporalarına yaklaşımlarına ilişkin en önemli paradigma değişimi diasporanın geri dönüşü üzerinedir. Günümüzde devletler, 90'll yıllara kadar yürüttükleri kampanyaların aksine, artık yurtdışındaki nüfuslarının nüfus hareketleri yoluyla toprağa dâhil edilmesi (territorialising) için değil, toprak-aşırılaştırma (transterritorialising) ve diasporize edilmeleri (diasporising) için çaba harcamakta ve buna uygun politik enstrümanlar (çifte vatandaşlık, siyasi katılım hakkı vb.) geliştirmektedir (Okyay, 2015, s.42).

Politika sahasında diaspora gruplarına yönelik yükselen bu ilgi, alanyazındaki akademik çalışmaların da artmasına sebep olmuş ve diaspora yönetimi ve politikalarına ilişkin bir takım kuramsal yaklaşımlar ortaya çıkmıştır. Bu politikaların motivasyonlarına ve köken ülke-diaspora ilişkilerine yönelik olmak üzere iki başlık altında incelenebilecek olan bu yaklaşımları aşağıdaki şekilde ele almak mümkündür.

\section{Diaspora-Köken Ülke İlişkileri}

Dünya tarihinin uzunca bir döneminde, yurtlarından çıkmış olan nüfuslar devletler için kaybedilmiş uyruklar olarak düşünülmüş ve devletlerin ilgilerinin dışında kalmışlardır. Ancak 18. Yüzyıl sonunda devlet ile halkları arasında resmi bir bağ kuran 'yurttaşlık' ilişkisinin icadıyla, yurttan 'çkmış' olanlar dahi kendisini denetleyen ve koruyan devletin sinırları içinde kabul edilmekte ve devletler bu topluluklarla bağlarını sürdürmek iradesini göstermektedir. Buna bağlı olarak, devletlerin yurtdışındaki vatandaşları yahut vatandaşı olmasa dahi- bu grupların soyundan gelenlere ilişkin politikalar üretmeleri ve bu politikaları hem vatandaşlar hem de ulusal kökenli grupları aynı şemsiye altında toplamaya izin veren diaspora terimiyle adlandırmaları çok yakın tarihlidir (Dufoix, 2011, s.82-83).

Diaspora kavramının, birçok grubu imleyecek şekildeki esnek doğası nedeniyle devletler tarafından kendi siyasi ajandalarına uygun bir kurgu ve 
sosyo-politik bir araç haline dönüştürüldüğü hususu alanyazında sıkça dile getirilmektedir (Dufoix, 2011; Brubaker, 2005; Wahlbeck, 2002; Brubaker ve Kim, 2011). Bu noktadan hareketle Brubaker ve Kim (2011), diaspora politikasının öncelikli olarak bir "tanımlama" politikası (politics of identification) olduğunu ve devletlerin sınırları dışındaki nüfusları belirli özellikler temelinde tanımlayarak köken-ülkeye aidiyetleri konusunda bir bilinç oluşturmaya çalıştığını ifade etmektedir (s. 24). İdeal diaspora tanımları yoluyla devletler hangi grupların diasporaya dâhil edilip hangilerinin edilmeyeceği ve diaspora topluluklarından beklenilen davranış modelleri ve aidiyet pratikleri gibi hususlarda sınırları çizebilmektedir (Dufoix, 2011, s.13).

Bunun yanında, diasporaların sayısal verilerle açıklanması gerektiğinde bu tanım setinin göz ardı edildiği ve sınıflandırmalar göz ardı edilerek maksimum toplamı ifade eden verilerin tercih edildiği görülmektedir (Brubaker, 2005, s.11). Bu noktaya dikkat çeken Dufoix (2011, s. 64), rejimle sıkıntılı olan siyasi göçmenlerin diaspora rakamlarına dâhil edilseler de, onları ayrıştıran farklılıkların genel etiketler yoluyla silikleştirildiğini söylemekte ve diaspora teriminin bu şekilde siyasi farklılıkları ortadan kaldırıcı ve tektipleştirici bir rol üstlendiğini belirtmektedir.

Tüm tektipleştirme çabalarına rağmen, diasporaların farklılıklar barınd1ran heterojen yapılar olduğu dikkate alındığında, bu farklı gruplarla anavatan arasındaki ilişkilerin de farklı olacağı açıtır. Buradan yola çıkan Dufoix, devletlerin yurtdışındaki nüfuslarıyla olan ilişkilerini dört temel model üzerinden açıklamaktadır. Bunlardan ilki, göç alan ülkedeki yerel örgütlenme biçimlerini tanımlayan dışa kapalı modeldir. Katılımcıların kendi aralarındaki dayanışmasını amaçlayan bu modelde, anavatandaki rejim ile herhangi bir ilişki içerisine girilmemektedir. İkinci model olan atopik yapılanmalarda, devlet-ötesi nitelik ön plana çımmaktadır. Dini yahut etnik ortak bir kimlik etrafında birleşerek, ne köken ülke ne de göç edilen ülke ile bağlantı içine girmeden, devletlerarasında var olma tarzına işaret eder. Bu yönüyle hem dişa kapalı hem de atopik model, resmi bir milliyet bağına dayanmadan ve köken ülke ile herhangi bir ilişki geliştirmeden varlığını sürdüren toplulukları ifade eder. Merkez-çevre modelinde ise, göçmenlerin ev sahibi ülkedeki varlığı ve örgütlenmesinde anavatanla ilişkiler büyük bir rol oynar. Bu modelde, göçmen toplulukları çoğunlukla 'ulusal diaspora' etiketi altında organize olur ve devletler de onları resmi kurumlar (elçilik, konsolosluk, eğitim kurumlar vb.) 
ve yerel örgütlenmelere sundukları destekler yoluyla konsolide eder. Devletler yurtdışındaki nüfuslarını resmederken çoğunlukla, bu toplulukları sadık kolonileri olarak gören bu modeli tercih ederler. Bunun karşısında, çatışmacı model, köken ülkedeki rejimin meşruluğunu kabul etmeyen yahut ülkelerinin yabancı işgali altında olduğunu düşünen grupları imlemekte olup, devletle karşıtlık ilişkisi içermektedir (Dufoix, 2011, s.66-71).

\section{Diaspora Yönetiminin Motiveleri}

Devletleri diaspora politikalarına iten sebepler konusu, son yıllarda diaspora yazınında tartışılan önemli konular arasındadır. Diaspora gruplarının sahip olduğu nitelik, nicelik ve diasporanın coğrafi dağılımdaki farklılıklar, diaspora yönetimi politikalarının ve bu politikalara temel teşkil eden motivelerin ülkeler arasında da farklılaşmasına neden olmaktadır (Brown, 2013, s.81). Ancak yine de bu geniş yelpazeden temel birkaç motivasyon çeşidini ayrıştırmak mümkün görünmektedir. Bu konunun teorize edilmesinde belki de en önemli adımları atan araştırmacılar Gamlen ve arkadaşları (2013)'dır. Araştırmacılar, kuramsal yaklaşım yanında ampirik boyutlar da içeren "Explaining the rise of diaspora institutions" isimli çalışmalarında, devlet destekli ulus-aşırılık (state-led transnationalism) olarak gördükleri diaspora politikalarını başlıca üç temel motivasyon altında toplamanın mümkün olduğunu söylemektedir.

Bunlardan ilki, göçmenlerin kaynaklarından faydalanmayı (tapping) ön plana çıkaran yaklaşımdır. Rasyonalist teoriye dayanan bu yaklaşım açısından, devletler uluslararası güç savaşında ekonomik ve sosyo-politik bir kaynak olarak gördükleri bu gruplardan anavatanlarına destek olmalarını talep etmektedir. Faydalanma yaklaşımının, diaspora politikalarını sömürücü bir merkez-çevre ilişkisi çerçevesinde şekillenen politikalar olarak gören pesimistik yorumları yanında, bu politikaları 'kazan-kazan' ilişkisi çerçevesinde okuyan neoliberal versiyonları da mevcuttur. Buna göre, uygun diapora yönetimi tasarlanabilirse, diaspora politikaları göç veren ve alan ülke yanında göçmenlere de fayda sağlayabilir. Bu yolla göç veren devletler ekonomik kalkınma için gerekli olan para, teknoloji ve bilgi transferine, göçmenler göçün organizasyonunda ve haklarının korunması noktasında ihtiyaç duydukları anavatan desteğine ulaşabileceklerdir. 
Diaspora politikalarını besleyen bir diğer motivasyon, göçmenlerin varlıklı yahut etkili pozisyonlarda olup olmadıklarına bakılmaksızın, köken ülke tarafından vatandaşlık yahut etnik bağ çerçevesinde kucaklanması (embracing) isteğidir. Bu kucaklama, iç politikadaki otoritelerini kuvvetlendirmek isteyen sağ ve otoriter rejimler tarafından kullanılabileceği gibi, hukuki bir vatandaşlık tanımı çerçevesinde yurt sınırları dışındaki vatandaşların haklarının savunulmasını ve bağların korunmasını önceleyen devletler için de önemli imkânlar sunmaktadır. Son durum, demokratik ülkelerin de bu politikaları kullanma gerekçelerini açıklayabilmektedir.

Gamlen ve arkadaşlarının sunduğu üçüncü yaklaşım ise, yönetim yaklaşımıdır (governing). Bu yaklaşım, uluslararası ilişkilerde belirli normların yayılım yoluyla benimsemesi ve içselleştirmesi süreçlerini ve devlet davranışlarının içinde bulundukları çevre ile etkileşimleri neticesinde nasıl birbirlerine benzer hale geldiklerini inceleyen kurumsal teoriden (institutionalism) beslenmektedir. Buna göre, ülkeler diaspora politikalarını, diasporanın nasıl en iyi yönetileceği konusunda küresel bazda oluşan yaygın kabuller ve politika örneklerine göre dizayn etmektedirler. Gamlen ve arkadaşlarına göre, devletler arasında karşılıklı bir bağımlılığı zorunlu kılan göç yönetiminde ev sahibi ülkelerin tek aktör kabul edildiği klasik anlayışın yarattığı yönetim boşluğu, diaspora kurumlarının inşası ile doldurulmaya çalışılmaktadır.

Bu üç yaklaşım tarafından diaspora yönetiminin oluşumuna etki ettiği tahmin edilen faktörlerin istatistiki bir modelini oluşturarak, araştırmasına ampirik bir boyut kazandıran Gamlen ve arkadaşları, 1990-2010 yılları arasında 144 ülke için 2377 verinin kullanıldığı bir veri setinden faydalanmıştır. $\mathrm{Bu}$ araştırma sonucunda Gamlen ve arkadaşları, devletlerin menfaatlerinin önemine işaret eden faydalanma perspektifinin diaspora politikaları için diğer iki yaklaşıma kıyasla daha açıklayıcı olduğunu, ancak bu üç yaklaşımın kombinasyonunun devlet-diaspora ilişkilerini anlamlandırabilmek için tek yol olduğunu ortaya koymaktadır (Gamlen vd., 2013, s.25).

Diaspora politikalarının ortaya çıkışı ve gelişimine kuramsal zeminde yaklaşan bir başka araştırmacı ise, Ragazzi (2014)'dir. Gamlen ve arkadaşlarının sınıflandırmasına paralel şekilde, bu politikaların gelişimini üç temel analitik çerçeve ile açıklayan Ragazzi'ye göre, bu çerçevelerden ilki devlet davranışlarını dünya ekonomisindeki konumuna (merkez yahut çevre) göre yorumlayan ve onları kâr/zarar hesabının bir çıktısı olarak gören yapısal- 
enstrümental yaklaşımdır. Buna göre, devletler ekonomik çıkarları doğrultusunda bir kaldıraç olarak diasporalarıyla ilişki kurmak istemektedirler. İkinci analitik çerçeve, milliyetçilik konseptinde meydana gelen değişimlere odaklanan etnik yaklaşımlardır. Ulusallaşmanın sona ermesi (denationalization), yeniden etnikleşme (re-ethnicization) (Joppke, 2003) ve uzaktan milliyetçilik (long-distance nationalism) (Anderson, 1998) gibi farklı hipotezler barındıran bu yaklaşım, temelde diaspora politikalarının değişen milliyet anlayışlarının bir sonucu olduğu savunmaktadır. Üçüncü analitik çerçeve ise, diaspora politikalarının 'refah liberalizmi'nden 'neoliberalizm'e geçişin etkisiyle şekillendiğini iddia eden siyasal-ekonomik hipotezdir (Ragazzi, 2014, s.82).

Ragazzi bu çalışmasında yukarıda bahsedilen teorik yaklaşımlar ışığında, çoklu uyum analizi (MCA) yöntemini kullanarak, 35 ülkenin diaspora politikası verilerini incelemiş ve şöyle bir sonuca varmıştır: Yapısal-enstrümental yaklaşım ve etnik temelli açılamalar diaspora politikalarının sebeplerini açıklamakta yardımcı olmakta, ancak yönetişim yaklaşımı, bu politikaların ulus-aşırılaşmasını ve topraktan bağımsız bir yönetim anlayışının gelişimini anlamak için daha geniş bir bakış açısı sunmaktadır (Ragazzi, 2014, s.87).

Gamlen ve Ragazzi'nin yaklaşımlarından yola çıarak, devletlerin diaspora politikası motivasyonlarına ilişkin kuramlarda şöyle bir sınıflandırmaya gitmek yanlış olmayacaktır:

- Diasporayı, ekonomi (para transferi, ticaret bağları, yatırımlar vb.), dış siyaset (anavatan lehine etnik lobi faaliyetleri) ve iç siyaset (siyasi elitlere sağladıkları meşruiyet) bağlamında anavatanın çıkarlarına hizmet eden bir kaldıraç olarak gören ve diaspora politikalarını bu motivasyon üzerinden açıklayan yaklaşımlar,

- Diaspora politikaların, devletlerin vatandaşlık yahut etnik aidiyet noktasından hareketle yurtdışında yaşayan göçmenlerine yönelik kucaklama anlayışılla hayata geçirdikleri politikalar olarak yorumlayan yaklaşımlar,

- Diaspora politikaların, daha geniş bir perspektiften, 1980'li yıllarda küresel politik-ekonomik sistemin yapısında meydana gelen değişimlerin (neoliberalizm) bir sonucu olarak gören yaklaşımlar

Alan yazında, bu temel motivasyonlara ilişkin destekleyici ve eleştirici çeşitli tutumlar yer almaktadır. Devletlerin yurtdışındaki gurbetçileri ile kurdukları bağı anlamakta aslan payını, gurbetçilerin sahip oldukları ekonomik 
potansiyele (Itzigsohn, 2000; Ostergaard-Nielsen, 2003), iç politikadaki başarının bir enstrümanı olarak oynadıkları role (Waterbury, 2010, s.140) yahut lobi faaliyetleri noktasında anavatana sunabilecekleri katkıya (Dufoix, 2011, s.93) verenler yanında, bu sayılan motivasyonların gerçekliğine kuşkuyla bakanlar da (Larner, 2007; Brand, 2008, s.217) mevcuttur. Bu bağlamda, Gamlen vd. (2013) ve Ragazzi (2014)'yi alanyazındaki diğer kuramlardan ayıran en önemli özellik, diaspora politikalarını anlamak için bir yahut birkaç motivasyon yerine, tüm etkenlerin beraber değerlendirilmesi gerektiğini ifade etmiş olmalarıdır.

\section{Türk Diaspora Politikası}

\section{Tarihî Seyir}

Türkiye'nin yurtdışına verdiği göçe yönelik politikalarının Cumhuriyetin ilk yıllarından başlayarak günümüze değin farklı evrelerden geçtiği görülmekte olup, bu politikaların ülkenin ekonomi-politik eğilimindeki değişimler ve siyasi kadrolar ile buna bağlı olarak ulusa yüklenen anlamdaki değişimlerden etkilendiği anlaşılmaktadır (Okyay, 2015). Bu bağlamda, Türk diaspora politikasını başlıca dört döneme ayırmak mümkündür: Cumhuriyetin ilk yıllarında nüfus mübadeleleri yoluyla ülke dışına verilen zorunlu göç dönemi (1923-1960), yurtdışına yönelen uluslararası işgücü göçü (1960-1980), 1980'ler sonrası ekonomik liberalleşme ve siyasi iltica hareketlerinin etkisiyle şekillenen dönem (1980-2002) ve son olarak 2000'li yıllardaki siyasi kadro değişiminin- AK Parti politikalarının şekillendirdiği dönem (2002 sonrası).

Cumhuriyet'in ilanı sonrası, nüfus mübadeleleri yoluyla Ermeni, Yunan ve Yahudi gibi gayri-Müslim toplulukların Türkiye'den yurtdışına gönderildiği ilk dönemde (Arı, 1999, s.97), bu göçler devletin “türdeş ulus" anlayışının bir gereği olarak görülmüş ve teşvik edilmiş olup, bu gruplar ile bağların devam ettirilmesi gibi bir çaba söz konusu olmamıştır (İçduygu, Erder, Gençkaya, 2014, s.313).

Türkiye'yi göçmenleriyle bağların devam ettirmek konusunda istekli bir göç veren ülke (migrant sending state) yapan asıl dönem, İkinci Dünya Savaşı sonrası Türkiye'den Avrupa'ya işgücü göçünün yaşandığı yıllar olmuştur. 1960'larda başlayan bu göç çerçevesinde, Türkiye işgücü desteğine ihtiyaç duyan birçok Batı Avrupa ülkesiyle ikili anlaşmalar imzalamış ve Türkiye İş 
ve İşçi Bulma Kurumu (İ̈BK) yoluyla 1974 yılına değin 800 bine yakın işçinin Avrupa'ya gönderilmesi sağlanmıştır (İçduygu vd., 2014, s.314).

Köyden kente göçün hızlandığı ve aynı hızla gelişemeyen sanayinin şehre göçenler için yeterli iş imkânı sunamadığı bu yıllarda Türkiye, hem ülkede artan işsizlik oranını düşürmeyi ve ekonomiye döviz girdisi kazandırmayı, hem de Türkiyeli işçilerin sanayileşmiş Batı Avrupa ülkelerinden edinecekleri bilgi birikimi ile ülkenin kalkınmasına katkı sağlamalarını hedeflemiştir. Bu hedeflerle teşvik edilen işgücü ihracı, 1963 ve 1968 yıllarında çıkarılan Beş Yıllık Kalkınma Planları'yla da desteklenmiştir (Abadan-Unat, 2006).

İşçi göçmenlerin ekonomik ve sosyal sermayesinden faydalanma amacındaki Türkiye'nin 80'li yıllara kadarki temel devlet politikası, bu göçün teşviki, döviz akışını ve geri dönüşleri kolaylaştırma yönünde olmuş (Bilgili ve Siegel., 2011, s.23) ve daha çok emeklilik vb. konularda Türk konsolosluklarında sunulan sosyal güvenlik hizmetlerine yoğunlaşılmıştır (Aydın, 2014, s.8).

Siyasi ilticaların etkisiyle politikaların odak noktasının ekonomik alandan politik alana kaydığı (Aydın, 2014, s.8) 80'li yıllar ile birlikte, marjinal gruplar için bir yaşam alanı haline geldiği düşünülen Avrupa'da, devletin kendisi için tehlike olarak gördüğü gruplar anavatanın menfaatleri doğrultusunda kontrol altında tutulmaya çalışılmış (Ulusoy, 2016, s.122-123) ve terminolojide sadece ekmek parası için göçen "fedakâr ve vatansever işçiler", "yıkıcı ve bölücü akımlara kapılan" göçmenlerden ayrılmıştır (Türkiye Büyük Millet Meclisi -Melen Hükümeti Programı). 1982 Anayasası ile devletin yurtdışındaki Türklerin menfaatlerini koruma zorunluluğuna yasal bir statü kazand1rılmış (Türkiye Cumhuriyeti Anayasası, 1982) ve böylece Türk diaspora politikasının önemli dönemeçlerinden birine girilmiştir (Ünver, 2013, s.185). Özellikle 1983 yılındaki siyasi elit değişimi (ANAVATAN Partisi) ve sonrasında neoliberal ekonomiye geçişin Türkiyeli göçmenlere yönelik politikaları etkilediği anlaşılmaktadır.

1986 yılında gümrüklerde seçimlerden 2-3 hafta önce oy kullanımının sağlanması (Keskin, 2017, s.542), siyasi retorikte entegrasyonun teşvik edilmesi (Aydın, 2014, s.9), Avrupa ülkelerine Türkçe öğretmenleri gönderilmesi (Aksel, 2014, s.11), Diyanet İşleri Başkanlığı altında Avrupa'da dini örgütlenmelerin sağlanması, 1996 yılında çıkarılan "Pembe Kart" uygulaması ve Bakanlıklar altında kurulan çeşitli hizmet birimleri (Bilgili ve Siegel, 2011, s.9) yoluyla Türkiye bu yıllarda yurtdışındaki göçmenlerine yönelik faaliyet alanını genişletmiştir. 


\section{Çağdaş Türk Diaspora Politikası}

Türkiye'nin bu alandaki asıl atılımını ise 2000'li yıllardan sonra gerçekleştirdiği görülmektedir. İlk kez 2002 yılında iktidar olan AK Parti yönetimi, Türkiye'de siyasi, ekonomik ve sosyal alanda belirgin değişimlerin yaşandığı bir transformasyon sürecini beraberinde getirmiştir. Sosyolojik olarak muhafazakâr ancak ekonomi-politik açıdan liberal bir parti olarak ortaya çıkan AK Parti, ilk hükümet döneminde demokratikleşme, ekonomik kalkınma ve Avrupa Birliği'ne tam üyelik gibi konularda önemli reformlara imza atmıştır. İhracat ve küresel pazarlara açlım temelli bir büyüme ve kalkınma anlayış1nın kabul edildiği bu dönemde, yurtdışından gelen direkt yatırımlar ve ekonominin hacmi de büyük oranda artmıştır (Öniş ve Kutlay, 2013).

Tüm bu olumlu gelişmeler, AK Parti'nin 18 yıllık dönemde girdiği tüm seçimleri kazanmasını ve asker ve hukukçuların da içinde olduğu sekülerulusalcı kanat karşısında güçlenmesini sağlamıştır. Bu durum "ulus" söylemine yüklenen anlamı dönüştürmüss, Osmanlı mirasına göndermeler ve İslami referanslar içeren bir ulus/millet konseptine geçilmiştir (Aydın, 2014, s.11). Muhafazakâr tandanslı bu ulus algısına uygun bir diaspora tanımının kabul gördügü dönemde, Türkiye kökenli insanlar açıkça diaspora olarak adlandırılmış ve buna yönelik bir kamu diplomasisi stratejisi benimsenmiştir. Aydın'a göre bu yaklaşım, AK Parti sonrası dönemdeki diaspora yönetimini eskisinden ayıran temel farklılıktır (Aydın, 2014, s.13).

Ermeni diasporasının Türkiye'ye yönelik olumsuz girişimleri düşünüldüğünde, siyasi retorikte yurtdışındaki Türkiye kökenlileri tanımlamada "diaspora" kavramının kullanılmaya başlanması, Türk diaspora politikasında önemli ve -kuramsal bölümde anlatıldığı üzere uluslararası gelişmelere uygun bir dönüşüm olarak görülmektedir. Çoklu kimlikleri kabule yatkın bu kavram, göçmenlerin bulundukları ülkelerdeki uyum süreçlerine yönelik desteği de beraberinde getirmiştir. Ancak bu yapılırken asimilasyon-entegrasyon ayrımına vurgu yapılmış ve çift taraflı ödevler sistemine dayalı bir uyum yaklaşımı sergilenmiştir. Erdoğan'ın 2008 yılında yaptığı Köln konuşması bunun önemli bir örneğidir. Bu konuşmada Erdoğan, asimilasyonun insanlığa karşı işlenmiş bir suç olduğunu söylemiş ve kendi öz kültüründen, öz dilinden taviz vermeden entegrasyonu savunmuştur ("Das sagte Ministerpräsident", 2008, 11 Şubat). 
Bunun yanında, ülke içerisindeki demokratik açılım yaklaşımının diaspora politikalarına da yansıdığı görülmektedir. O döneme değin yurtdışındaki vatandaşların önemli bir kısmına karşı sergilenen yukarıdan ve mesafeli tutumun (Ulusoy, 2016, s. 129) yerini "halkın içinden ve halka yakın" şeklinde tanımlanabilecek bir yaklaşıma bıraktığı görülmektedir. Bu yaklaşım, o döneme değin sağlanamadığı anlaşılan (Bkz. Kaya ve Kentel, 2005, s.48) diasporanın Türkiye devletine olan güven ve aidiyetini de artırmıştır (Okyay, 2015, s.137-138).

Bu dönemdeki Türk diaspora politikasını eskisinden ayıran en önemli gelişmelerden biri de, yumuşak güç (soft-power) kullanımına izin veren ve kamu diplomasisi faaliyetleri yürütmesi beklenen yeni kurum ve enstrümanların ihdas edilmiş olmasıdır. Dışişleri Bakanlığı, Milli Eğitim Bakanlığı, Çalışma ve Sosyal Güvenlik Bakanlığı ve Diyanet İşleri Başkanlığı gibi, Türkiyeli göçmenlerin kalıcılıklarının anlaşıldığı 80'li yıllardan itibaren faaliyet gösteren ve diaspora politikasının şekillenmesinde merkezi role sahip kurumlara, 2000 'li yıllardan sonra yeni kurumsal yapılar eklenmiştir. Türk diaspora politikasını derinden etkileyen en köklü değişiklik kuşkusuz, 2010 yılında kurulan Yurtdışı Türkler ve Akraba Topluluklar Başkanlığı (YTB)'dır. Dönemin Devlet Bakanı Bekir Bozdağ tarafından "Diaspora Bakanlı̆̆ı" olarak nitelenen bu kurum yoluyla, Türkiye hem yurtdışındaki vatandaşları hem de akraba topluluklarına yönelik politikaları yürütecek merkezi bir aktör tesis etmeyi amaçlamıştır (T.C. Başbakanlık). Soydaş ve akraba topluluklar ve uluslararası öğrenciler yanında temel görev alanı "Yurtdışı Vatandaşlar" olan kurumun "yurtdışı vatandaş" tanımı (Bkz. YTB, 2017, s.40), devletlerin diasporaların tanımlarken, maksimum toplamı hedeflediklerini söyleyen Brubaker (2005, s.11)'ın yaklaşımını destekler nitelikte- formel vatandaşlık yaklaşımının ötesinde alt soyları ve Türkiye'ye bağlllığı hesaba katan genişletilmiş bir tanımdır. Kurumda bu kapsamda yürütülen faaliyetlerde; diaspora mensuplarının kimlik ve kültürlerinin korunması, diasporanın anavatan aidiyetinin muhafaza edilmesi ve yaşadıkları ülkelerdeki sosyal ve ekonomik statülerinin yükseltilmesi gibi temel üç hedefin gözetildiği görülmektedir (YTB, 2017, s.40).

Türk diaspora politikasındaki bir diğer kurumsal yenilik, kültürel diplomasi aracı olarak Türkiye'ye uluslararası yumuşak güç anlamında katkı sunması amacıyla tasarlanan Yunus Emre Kültür Merkezleri (YEKM) olmuştur. 2009 yllından itibaren kurulmaya başlanan Enstitülerde, Almanya'ya bağlı 
"Goethe Institut", İngiltere'ye bağlı “British Council” ve İtalya'ya bağlı "Istituto die Studi Italiani" gibi yapıların model alındığı görülmektedir (Ünver, 2013, s.186). Bu Merkezler aracilığıyla yürütülen faaliyetler; Türkçe öğretimi, Türkiye'nin tanınırlı̆ııı artırmak hedefiyle organize edilen kültür sanat faaliyetleri ve Türkiye ile ilgili bilimsel ve akademik çalışmalar desteklenmesi ve bu alanda yeni işbirlikleri oluşturmak olarak özetlenebilir (Yunus Emre Enstitüsü, 2016). Faaliyetlerinin odağı yerel toplum olsa da, Merkezler gerek Türkçe dersleri ve Türk kültürünü tanıtan faaliyetler ile diasporanın kimlik muhafaza noktasında oynadıkları rol, gerek Türkiye imajının iyileştirilmesi yoluyla yabancı düşmanlığıyla mücadele noktasında sundukları katkı nedeniyle çağdaş Türk diaspora politikasının önemli enstrümanlarından biri haline gelmiştir.

Bu yeni aktörler yanında, Türkiye'nin diaspora politikası bağlamında AK Parti hükümetinin desteğiyle, ev sahibi ülkelerde kurulan Uluslararası Demokratlar Birliği (UID) isimli kuruluşlardan da bahsetmek gerekir. 2004 y1lından itibaren Avrupalı Türklerin yaşadıkları ülkelerde kurulmaya başlanan ve 'Avrupalı Türkler" ve "Türkiye Avrupa İlişkileri" gibi konularda faaliyet yürüten bu kuruluşlar, Avrupa ülkelerinin birçoğunda Türk hükümetinin bir uzantısı ve hükümet partisinin propagandasını yapan lobi kurumları olmakla eleştirilmektedir (Bundesministerium für Innern, für Bau und Heimat, 2018, s.287-288; “Das weite Netzwerk”, 16 Temmuz 2014).

Benzer şekilde 2013 yılında Düsseldorf'da UID tarafından düzenlenen "Respect for Democracy" (demokrasiye saygi) isimli konvoy, Gezi parkı protestoları döneminde hükümeti desteklemek için Türkiye'nin yönlendirmesiyle icra edilen bir lobi faaliyeti olarak yorumlanmaktadır (Aydın, 2014, s.26). Bu bağlamda, mevcut faaliyet ve gündemleri dikkate alındığında birliğin zamanla Türk iç siyasetinin konularını odak noktası haline getirdiği (Akçapar ve Aksel, 2017, s.154); UID’lerin Türkiyeli göçmenlere hizmet eden bir yap1dan çok AK Parti'nin yurtdışı temsilciliği olarak algılandığı (Şimşek, 2017, s.184) ve bu yönüyle yurtdışında yaşayan vatandaşlara faydadan çok zarar getirdiği şeklinde yorumlar ön plana çıkmaktadır.

Diğer yandan, bu eleştirileri dillendiren Almanya ve Avusturya gibi çeşitli Avrupa ülkelerinin bizatihi kendilerinin de Türk diasporasının belirli kesimlerini kendi amaçları doğrultusunda araçsalaştırdıkları görülmektedir. Örneğin, PKK, DHKP-C gibi aşırı sol ve ayrılıkçı grupların da dâhil olduğu Türkiye karşıtı bir kitlenin, Alman devleti tarafından desteklendiği ve Türkiye'ye 
yönelik baskı politikalarının bir enstrümanı olarak kullanıldığ1 (Unat, 2017) ve resmi olarak bir terör örgütü kabul edilmesine rağmen benzer grupların mitinglerine göz yumulan Avusturya'da, PKK sempatizanı oldukları bilinen bazı siyasi aktörlerin uzun yıllardır desteklendiği, Türkiye karşıtı eylem ve protestolara doğrudan Avusturya devleti tarafindan alan açıldığı (Eliaçık, 2019) sıklıkla dillendirilen meseleler arasındadır.

Yukarıda zikredilen yeni ihdas edilen kuruluşlar yanında, yurtdışındaki vatandaşların sosyal, siyasal, ekonomik, kültürel vb. alanlarda karşılaştıkları sorunlarının tespit ve çözümüne yönelik, kendi görev sahaları çerçevesinde faaliyet yürüten Bakanlıklar ve kuruluşların faaliyet ve etki alanlarının da son yıllarda arttığı görülmektedir. Bu bağlamda, Dışişleri Bakanlığı bünyesinde yürütülen konsolosluk hizmetlerinde yukarıda bahsedildiği üzere devletle mesafenin azaltıldığı bir dönüşüm yaşanmış; Aile ve Sosyal Politikalar Bakanlığı (ASPB) bünyesinde yurtdışı teşkilatlanmaya gidilerek Avrupa'daki Türk vatandaşlarına yönelik "Aile ve Sosyal Politikalar Ataşelikleri" açılmıştır (ASPB). Bunun yanında, Milli Eğitim Bakanlığı (MEB)'nın Büyükelçilikler ve Başkonsolosluklar bünyesindeki eğitim müşavirlik ve ataşeliklerinin sayısı artırılmıştır (T.C. Milli Eğitim Bakanlığı, t.y.).

Diaspora politikasının en eski aktörlerinden biri olan Diyanet İşleri Başkanlığı'nun faaliyetlerinin kapasite ve yoğunluğunun AK Parti döneminde daha da arttığı görülmektedir. Bu dönemde yurtdışına din görevlisi yetiştirmek ve bu hizmetlerin yerel kültüre aşina kişiler tarafından sunulmasını sağlamak amacıyla "Uluslararası İlahiyat Programı" (Uİ) geliştirilmiş (Erşahin, 2015), Başkanlık ve yurtdışındaki yapılanmaları (DİTiB-Diyanet İşleri Türk İslam Birlikleri) din ve Türk kültürünün öğretimi, asimilasyonun önlenmesi gibi konularda çalışmalarını artırmışlardır. Ancak bu faaliyetleri ile yurtdışındaki Türkiyeli toplumun anavatanlarına aidiyet ve bağlılığını korumaya çalışan DİTiB teşkilatları, modern diasporaya doğru evrilen Türk toplumunun entegrasyonunda olumsuz sonuçlar yaratabileceği (Ulusoy, 2016, s.146147) ve Türkiye'nin ev sahibi ülkelerin iç işlerine karışmak için kullandığg birer enstrüman oldukları (Steinvorth, 29 Mayıs 2019; "ATIB: Der verlängerte", 8 Haziran 2018) gerekçesiyle eleştirilmektedir.

Kurumsal altyapının çeşitlendirilip sağlamlaştııldı ğı bu yıllarda, göçmen nüfusa yönelik daha etkin politikalar yürütmek amacıyla yeni bir takım enstrümanlar da geliştirilmiştir. Bunlar arasında, esnek vatandaşlık, kısa dönem yahut bedelli askerlik gibi uygulamalar yanında, yurtdışından Türkiye'nin 
seçimlerine katılım ve mavi kart ile genişletilen haklar gibi uygulamalar ön plana çımaktadır (Aksel, 2014, s.17). Bu bağlamda, yurtdışındaki Türk vatandaşları ilk kez 2014 Cumhurbaşkanlığı seçimleri için gümrük kapıları yanında bulundukları ülkenin yurtdışı temsilciliklerinde de oy kullanabilmiştir (Keskin, 2017, s.549-550). Bu, her seçimde oy kullanma oranlarının giderek artmasına sebep olmuş ve diasporanın Türk siyasetine angaje olup, beklenti ve taleplerinin parti programlarında dikkate alınmasına imkân sağlamıştır (Göç Araştırmaları Vakfı, 2018).

Yeni diaspora politikasını önemli enstrümanlarından biri de Mavi Kart uygulamasıdır. Başta Almanya ve Avusturya olmak üzere Avrupa ülkelerinin birçoğu, çifte vatandaşlığa izin vermediğinden, Türkiye göçen insanlarının Türk vatandaşlı̆̆ından çıkması halinde anavatanda sunulan hakları korumak için bu uygulamayı yürürlüğe sokmuştur. (Keskin, 2017, s. 547). Bu dönemde ayrıca, diaspora üyelerine yönelik sosyo-ekonomik desteklerin de arttı̆̆ görülmektedir. Uzun yıllardır şikayet konusu olan yüksek pasaport harçları, diaspora lehine yapılan bir düzenleme ile yarıya düşürülmüş, dövizle askerlik bedeli 6 bin avrodan bin avroya indirilmiştir. Mikro alanda sunulan bu katkı ve destekler, makro alanda anavatan ile bağların sağlamlaştırılması adına önemli adımlar olarak değerlendirilmektedir (Yeneroğlu, 2016).

\section{Kuramlar Çerçevesinde Türk Diaspora Politikasını Anlamak}

Çalışmanın ilk bölümlerinde, diaspora kavramı, köken ülke ve diaspora arasındaki ilişkiler ve devletlerin diaspora politikaları yürütme noktasındaki motivasyonları konularında öne çıkan çağdaş kuramsal yaklaşımlar ele alınmıştı. Son yıllarda önemli atılımların gerçekleştiği Türk diaspora politikası söz konusu olduğunda, bu kuramların açıklayıcılıklarının ne olduğu sorusuna çalışmanın bu bölümünde cevap aranacaktır.

Türkiye'nin 2000'li yıllarda diaspora yönetimi konusunda esen küresel rüzgârdan etkilenerek, yurtdışındaki diasporası ile daha yakın ilişkiler kurmaya başladığı görülmektedir. Yeni Türk diaspora politikasında göze çarpan en önemli dönüşümlerden biri, olumsuz manalar barındıran klasik diaspora kavramından çağdaş diaspora kavramına geçişin sağlanarak, Türkiye kökenli insanların açıkça diaspora olarak adlandırılmaya başlanmasıdır.

Tıpkı, Cumhuriyet'in ilanı sonrası, nüfus mübadeleleri yoluyla göç eden gayri-Müslim toplulukların (İçduygu, 2014, s.313) ve 1980 darbesi sonrası 
Türkiye'den göçen Kürt ve Alevi kökenli vatandaşların (Ostergaard-Nielsen, 2003) ideal diaspora tanımının dışında bırakıldığı yıllarda olduğu gibi, son dönem diaspora politikasının da kendi ideal diaspora tanımını ürettiği görülmektedir. Ülke içinde belirlenen ideal vatandaş tanımına paralel şekilde, muhafazakâr tandanslı yeni bir millet görüşüne dayanan bu yeni diaspora tanımı (Aydın, 2014), çalışmanın kuramsal çerçeve bölümünde ele alınan Brubaker ve Kim (2011)'ın yapısalcı yaklaşımına uygun şekilde, devletin hangi grupların diasporaya dâhil edilip edilmeyeceği konusundaki tanımlama gücünü göstermesi açısından önem arz etmektedir.

Bunun yanında, çağdaş Türk diaspora politikasındaki bir diğer önemli gelişme, dünyada devletler bünyesinde kurulan diaspora kurumlarının artışına paralel şekilde Türkiye'de de diaspora politikalarına yönelik yeni bir takım aktör ve enstrümanların ihdas edilmiş olmasıdır. Özellikle, diaspora yönetiminde merkezi bir diaspora kurumu olarak tasarlanan YTB'nin kuruluşu Türkiye'nin bu politika alanında artan ilgisini göstermesi bağlamında dikkate değerdir. "Yumuşak güç" kullanımına izin veren YEKM gibi kurumlar yoluyla da Türkiye'nin göçmenlere yönelik politikalarının kamu diplomasisi ile buluştuğu görülmektedir. Bunun yanında, dünya örneklerine benzer şekilde Türkiye tarafindan yurtdısındaki nüfusunun toprağa dâhil edilmesi (territorialising) değil, diasporize edilmesine (diasporising) yönelik yeni enstrümanlar da geliştirilmiştir. Bu bağlamda, diasporanın geri dönüşü yerine, bulundukları ülkelerdeki entegrasyonu teşvik edilmekte ve kapasite geliştirme çalışmalarına ağırlık verilmektedir. Ayrıca, çifte vatandaşlığın mümkün olmadığı ülkelerde, mavi kart ve yurtdışından seçimlere katılım gibi esnek politik enstrümanlar devreye sokulmaktadır. Böylelikle hem diaspora üyelerinin bulundukları ülkelerin vatandaşları olmalarını teşvik eden devlet politikası yürütülmeye devam edilmekte, hem de anavatanda bu gruplar için sunulan haklar garanti altına alınabilmektedir (Keskin, 2017, s.547). Tüm bu gelişmeler dikkate alındığında, Türkiye'nin diaspora konusunda alanyazında resmedilen ve uluslararası arenada gerçekleşen dönüşümlere ayak uydurduğu görülmektedir.

Türkiye'nin diasporasıyla kurduğu ilişkinin niteliği ve bunun hangi teorik çerçeveyle izah edilebileceği konusu da önemlidir. Çalışmanın kuramsal çerçeve bölümünden hatırlanacağı üzere, devletlerin diasporalarıyla geliştirdikleri ilişki modellerinden biri olan "Merkez-Çevre" modeli (Dufoix, 2011) dev- 
letlerin diasporalarını konsolide etme ve yönlendirmede etkin birer aktör olduklarını kabul etmektedir. Göçmenlerin örgütlenmelerinde anavatanla ilişkilerin büyük bir rol oynadığı bu modelin, Türkiye'nin diasporasıyla geliştirdiği ilişkiyi açıklamakta daha başarılı olduğu söylenebilir. Nitekim, diasporanın Türkiye' nin çeşitli resmi kurumları (elçilik, konsolosluk, eğitim kurumlar vb.) ve yerel örgütlenmelere sunulan destekler yoluyla anavatan ile güçlü bağlar çerçevesinde organize ve konsolide edilmek istendiği (Ulusoy, 2016; Aydın, 2014) ve göçmenlerden Türkiye'nin iç meselelerine yönelik ilgi beklendiği (Akçapar ve Aksel, 2017; Ünver, 2013) anlaşılmaktadır.

Türk diaspora yönetiminde görülen dönüşümün arkasında hangi motivasyonların yer aldığı sorusu da alan yazında tartışılan önemli konulardan biri olmuştur. Bu bağlamda, bu çalışmada ele alınan temel kuramsal yaklaşımların Türk diaspora politikasının motivasyonlarını açıklarken de kullanıldığı görülebilmektedir. Örneğin; Aydın (2014), Türkiye'nin son yıllarda diasporaya yönelik artan ilgisini ekonomik ve siyasi menfaatler çerçevesinde değerlendirmektedir. Aydın'a göre, siyasi ve toplumsal temsiliyeti ve organizasyon yeteneği gün geçtikçe artan Avrupa'daki Türk diasporası, Türkiye tarafından önemli bir kaynak ve Türkiye'nin yurtdışındaki doğal uzantısı olarak görülmekte ve bu nedenle desteklenmektedir. Türk diasporasının AB'ye üyelik başta olmak üzere, ev sahibi ülkelerde yürütülecek lobi faaliyetleri, yaşadıkları ülkeler ile Türkiye arasındaki ticaretin ve ülkeye yabancı sermaye girişinin artırılması ve Türkiye'nin dış yatırım imkânlarının çeşitlendirilmesi yönünde sunabileceği katkılar Türkiye'nin diasporayı desteklemek konusundaki istekliliğini büyük oranda açıklamaktadır. Özellikle, Türkiye Odalar ve Borsalar Birliği (TOBB) gibi ekonomik kuruluşların, Türkiye tarafından etkin bir diaspora politikası yürütülmesi konusundaki tavsiyelerini örnek gösteren Aydın, diaspora politikalarını şekillendiren en önemli unsurun ekonomik menfaatler olduğunu dile getirmektedir (Aydın, 2014) .

Benzer şekilde, Aksel $(2014$, s.19) de, Türk devleti tarafından diasporanın öncelikle siyasi ve ekonomik bir kaldıraç olarak görüldüğünü ifade etmekte, Türkiye'de "diaspora" kavramını ilk olarak sermaye çevreleri ve ekonomik kuruluşlar tarafından kullanılmaya başlanıp daha sonra politik alana yayılmış olmasını bunun bir kanıtı olarak göstermektedir.

Öncesinde de bir takım girişimler olmasına karşın, esasen AK Parti iktidarları tarafından fark edilen diasporanın ekonomik ve siyasi gücüne deği- 
nen Keskin (2017)'e göre de, çoğunlukla Batı Avrupa ülkelerinde yerleşik bulunan Türkiye diasporasının Türkiye-AB ilişkilerinin geliştirilmesinde oynayabileceği katalizör rolü, diaspora politikalarının gelişiminde ve şekillenmesinde oldukça etkili olmuş ve Türkiye, dış politik açılımlarına yardımcı unsur olarak diasporayı daha fazla ihmal etmek istememiştir. Bekir Bozdağ'ın diasporanın yaşadıkları ülkelerdeki toplumsal katılım ve entegrasyonunun teşviki konusunda 2012 yılındaki şu sözleri de bu yaklaşımı doğrular niteliktedir:

Vatandaş oldukları ve eşit haklara sahip oldukları zaman, oradaki istihdama, eğitime, siyasete, her alana daha etkin katılımları olacak ve hem orada yaşayan vatandaşlarımıza, soydaşlarımıza, akrabalarımıza hem de Türkiye'yle yaşadıkları ülkenin ilişkilerinin sağlıklı olmasına daha büyük katkılar sunma imkânı bulacaklar. (Zentürk ve Bozdağ, 2012, s.5)

Ancak Keskin, yeni dönem Türk diaspora politikasını sadece anavatanın menfaatleri temelinde açıklamanın da doğru olmadığını düşünmektedir. Ona göre AK Parti hükümetleri yaptıkları icraatlar yoluyla, uzun yıllar dışlanmış ve sahipsiz bırakılmış Türk diasporasını kucaklamakta ve bu kesimlerin hak ve özgürlüklerini yüksek sesle dillendirilerek sorunlarına çözüm üretmeye uğraşmaktadır (Keskin, 2017, s. 550-551). Türk diaspora politikası söz konusu olduğunda bu yorumun, diaspora politikalarını tek taraflı bir faydalanmadan ziyade, hem göç veren ülke hem de göçmenler açısından 'kazankazan' ilişkisi çerçevesinde gören neoliberal yaklaşımları haklı çıkardığı görülmektedir.

Buna benzer şekilde, son dönemdeki Türk diaspora politikasının önemli bir politik sıçrama olarak görülmesi gerektiğini söyleyen Ulusoy (2016, s.128129) da, bu dönemde merkezden itilmiş belirli kesimlerin haklı kırgınlıklarını giderme noktasında ciddi adımlar atıldığına değinmektedir. Bununla beraber, Ulusoy söz konusu politikanın şekillenmesinde iş çevrelerinin önemini kabul etmekte ve bu konuda TOBB ve Dış Ekonomik İlişkiler Kurulu (DEIK) gibi kuruluşların faaliyetlerinden örnekler vererek diasporanın inşasında oynadıkları birincil rolü ifade etmektedir. DEIK bünyesinde yıllık olarak düzenlenen "Dünya Türk Girişimciler Kurultayı", diasporayla ilişkilerin geliştirilmesine yönelik anlaşmalar ve spesifik olarak diaspora konusunda hazırlanmış ilk rapor olan “Dünyada Diaspora Stratejileri: Türk Diasporası için Öneriler" isimli çalışma söz konusu kuruluşların Türkiye'de diaspora inşası konusundaki öncü rolünü göstermesi açısından önemlidir (Ulusoy, 2016, s.168). 
Görüldüğü gibi; alan yazında son dönemde Türkiye'nin diasporaya yönelik ilgisindeki artışın ardında birden fazla saikin rol oynadığından bahsedilmektedir. Bütüncül bir okuma yapıldığında, göçmenlerin ekonomik ve siyasi kaynaklarından faydalanmayı (tapping) ön plana çıkaran yaklaşım yanında göçmenlerin anavatan tarafından vatandaşlık yahut etnik bağ çerçevesinde kucaklandıklarını (embracing) savunan yaklaşımın da Türk diaspora politikasını açıklamakta yardımcı olabildiği görülmektedir. Bunun yanında, yeni Türk diaspora politikasının enstrüman ve kurumları oluşturulurken dünya örneklerinden etkilenildiği ve bu bağlamda neoliberal göç yönetimi anlayışının yaygınlaşmasının da diaspora politikalarının oluşumunda etkili olduğu söylenmelidir.

\section{Sonuç}

Diaspora kavramının travmatik unsurlarından kurtulması, küreselleşme süreci ve diaspora grupları ile ekonomik ve beşeri kalkınma arasında kurulan olumlu ilişki gibi gelişmelerin etkisiyle şekillenen çağdaş diaspora yönetimi, 2000'li yıllar sonrası küresel düzeyde yaygınlık kazanmıştır. Özellikle, 2002 AK Parti iktidarı sonrası dönemde bu küresel rüzgarın etkisiyle önemli adımlar attığı görülen Türkiye'nin, diaspora alanındaki politika ve uygulamalarını yaygınlaşan bu yeni kabul ve eğilimlere uygun olarak dizayn ettiği görülmektedir.

Diasporanın sınırlarını belirleme yetkisini elinde bulundurduğu görülen devletin bu yıllarda, etnik olmaktan ziyade dini-tarihi arka plan barındıran ve çoklu kimliklere imkan tanıyan bir diaspora kavramına yaslandığı anlaşımaktadır. Küresel eğilimlere paralel şekilde, diaspora üyelerinin geri dönüşü değil, diasporize edilmeleri üzerine kurulu bir stratejinin benimsendiği bu dönemde, bu stratejiye uygun ve "yumuşak güç" kullanımına izin veren yeni kurum ve enstrümanların ihdas edildiği görülmektedir.

$\mathrm{Bu}$ politikaların motivasyonlarına yönelik kuramsal yaklaşımlar açısından değerlendirdiğimizde, Türkiye'nin çağdaş diaspora yönetiminin oluşumuna etki eden faktörlerin çok çeşitli olduğu söylenebilir. Bu bağlamda, çok önemli bir motivasyon kaynağı olduğu görülse de, Türk diaspora politikasını sadece vatandaşlık temelli bir yurttaşlık anlayışından hareketle, göçmenlerin haklarının savunulması ve bağların korunması için icra edilen kucaklayıcı uygulamalar olarak sunmak meseleyi tam manasıyla açılayamamaktadır. İç 
içe geçmiş birçok motivasyonun beslediği anlaşılan bu politikaların, göçmenlerin kaynaklarından anavatan lehine faydalanma motivasyonunu da önemli ölçüde barındırdığı ve ayrıca küresel göç yönetimi anlayışının sunduğu kalıplardan da ilham aldığı görülmektedir. Bu durumun, çağdaş Türk diaspora politikası söz konusu olduğunda, devletlerin bu politikalara eğiliminde en açıklayıcı motivasyonun faydalanma yaklaşımı olduğunu ve fakat kucaklama, uluslararası göç yönetimine uyum gibi motivasyonların etkisi göz ardı edildiğinde konunun tam manasıyla anlaşılmayacağını vazeden bütüncül yaklaşımları haklı çıkardığı ortadadır. 


\title{
EXTENDED ABSTRACT
}

\section{Contemporary Theoretical Approaches to Diaspora Policies and Turkish Diaspora Policy}

\author{
Esra Sağlam
}

TUBITAK

The concept of diaspora seems to have been freed with 20th century from the overwhelming weight of its classical conceptualization, which contained traumatic elements and pointed to historical Jewish and Armenian diasporas. Once disdained as 'victims', diasporas are now presented as 'national heroes' in events such as diaspora congresses. As individuals with multiple cultures and belongings, they are acclaimed for their contribution to the homeland (Gamlen, Cummings, Vaaler, Rossouw, 2013 , p.4).

Both these connotations of the concept of diaspora evolving positively and the discovery of diaspora groups as economic and cultural instruments by countries have greatly increased the interest of the states in these groups. As a result of this situation, which is named as the "diaspora turn" (Agunias, 2009) in the literature, more and more countries and international organizations around the world are developing policies for the purpose of developing collaborations with communities abroad. In addition, diaspora management is encouraged by international organizations, multiple platforms and research organizations (Kuznetsov and Sabel, 2006; International Organization of Migration, 2013; The United States Agency for International Development, 2013). Another transformation in diaspora policies is the rise of a citizenship concept detached from land and the development of some political instruments in line with this strategy by governments (Okyay, 2015, p. 42).

This increasing interest in diaspora groups in the field of politics has also increased the number of academic studies. Accordingly, new theoretical approaches regarding diaspora management and policies have emerged.

The aim of this study is to understand what current theoretical approaches contribute to explaining contemporary "Turkish Diaspora Policy". In this context, firstly the theoretical approaches that are prominent in the literature about the relationship between the country of origin and the diaspora are discussed. Secondly, the theoretical approaches regarding diaspora policies are 
addressed that are directed towards the motivations of these policies, in order to understand why states engage their members abroad.

Based on the approaches of Gamlen et al. (2013) and Ragazzi (2014) (who made important contributions to the theorization of this fairly new subject), in this study, the following theoretical classification was made regarding the diaspora policy motivations of states:

- Approaches that view the diaspora as a leverage that serves the interests of the homeland in the context of economy, foreign and domestic politics, and explain the diaspora policies through the mentioned motivation,

- Approaches that interpret diaspora policies as being based on citizenship or ethnic belonging and implemented by states with an embracing motivation for their migrants living abroad,

- Approaches that view diaspora policies from a broader perspective. More specifically, as the result of changes in the structure of the global political-economic system (neoliberalism) in the 1980s.

When evaluating the opportunities presented by these theoretical approaches in understanding the contemporary Turkish diaspora policy, some important conclusions have been reached in the study.

In the AK Party era of 2002 and onward, Turkey administration has taken important steps in this policy area. It seems to have designed its diaspora policies in accordance to the new global trends and affirmations. One of the most important transformations in new Turkish diaspora policy is Turkey's actions in establishing closer relations with the diaspora members and ensuring the transition from the classical definition to the contemporary definition of diaspora. As a result, people of Turkish origin are openly referred to as Diaspora.

It is understood that the state, which has been found to have the authority to determine the borders of the diaspora concept, has relied on a diaspora concept that allowed for multiple identities by basing the concept of diaspora, on a religious-historical background rather than an ethnic one.

In line with global trends, a strategy has been followed, which is based on diasporising, rather than the return of diaspora members. Additionally, integration of diaspora members in their host countries has been encouraged, capacity building activities have been focused on and flexible political instruments such as participation in political elections from abroad and "Blue Card" opportunities where dual citizenship is not possible, have been implemented. 
In these years, new institutions and instruments that allow the use of "soft power" have been created. The establishment of the "Presidency for Turks Abroad and Related Communities" as a central institution in the diaspora management is especially remarkable in the context of showing growing interest in this policy area in Turkey. It is also apparent that Turkey's policies regarding migrants have come together with public diplomacy through the establishment of institutions such as the "Yunus Emre Cultural Centers".

Also, it is observed that, among the relationship models expanded by states for their respective diaspora, the "centro-peripherial" model is more successful in explaining the relationship Turkey has developed with its diaspora members. In accordance with this model, in which relations with the homeland play a major role in the organization of migrants, Turkish diaspora have been organized and consolidated within the framework of strong tie to the homeland through various official institutions and support provided to local organizations.

In terms of theoretical approaches to the motivations behind diaspora policies, it can be mentioned that the factors affecting the formation of contemporary Turkish diaspora management are quite diverse. Although it seems to be a very important source of motivation, to define the new Turkish diaspora management as a policy based on citizenship and being implemented only with the motivation for embracing members abroad and defensing of the migrants' rights, cannot entirely explain the issue. This study shows that these policies driven by a variety of intertwined motivations contain the motivation of benefiting from the resources of migrants in favor of the homeland and are also inspired by the patterns offered by the global migration management approach. In the case of contemporary Turkish diaspora policy, the results of this study justify the holistic approaches that see using the motivations like the "tapping", "governance" and "embracing" together as the most convenient way to understand why states engage their members abroad by establishing diaspora institutions.

\section{Kaynakça / References}

Abadan-Unat, N. (2006). Bitmeyen göç: Konuk işçilikten ulus-ötesi yurttaşlı̆̆a. 2. Baskı. İstanbul: Bilgi Üniversitesi Yay. 
Agunias, D., R. and Newland, K. (2012). Developing a road map for engaging diasporas in development: A handbook for policymakers and practitioners in home and host countries. Geneva: International Organization for Migration. 5 Nisan 2020 tarihinde, http://publications.iom.int/system/files/pdf/diaspora_handbook_en_for_web_28may2013.pdf adresinden erişildi.

Agunias, D. R. (Ed.) (2009). Closing the distance: How governments strengthen ties with their diasporas. Washington, DC: Migration Policy Institute.

Akçapar, Ş. K. and Aksel, D. B. (2017). Public diplomacy through diaspora engagement: The case of Turkey. Perceptions, 22(4), 135-160.

Aksel, D. B. (2014). Kins, distant workers, diasporas: Constructing Turkey's transnational members abroad. Turkish Studies, 15(2), 195-219.

Anderson, B. (1998). The spectre of comparisons: Nationalism, southeast Asia, and the world. Londra: Verso.

Sosyal yardımlara ayrılan mali kaynak 2002 yılında 1,4 milyar lira iken, 2016 itibarıyla bu miktar 32 milyar liraya yükseldi. Bu tutarın, 2017 yılı sonunda yaklaşık 38.3 milyar lira olarak gerçekleşmesini öngörüyoruz (2017). Aile ve Sosyal Politikalar Bakanlı̆̆ll ASPB. 12 Nisan 2020 tarihinde, https://www.aile.gov.tr/haberler/sosyal-yardimlara-ayrilan-mali-kaynak-2002-yilinda-1-4-milyar-lira-iken-2016-itibariyla-bu-miktar-32milyar-liraya-yukseldi-bu-tutarin-2017-yili-sonunda-yaklasik-38-3milyar-lira-olarak-gerceklesmesini-ongoruyoruz adresinden erişilmiştir.

“ATIB: Der verlängerte Arm Erdogans in Österreich" (8 Haziran 2018). OÖ-Nachrichten. 21 Mart 2020 tarihinde, https://www.nachrichten.at/politik/innenpolitik/ATIB-Der-verlaengerte-Arm-Erdogans-in-OEsterreich;art385,2919051 adresinden erişilmiştir.

Aydin, Y. (2014). The new Turkish diaspora policy: Its Aims, Their limits and the challenges for associations of people of Turkish origin and decision-makers in Germany. SWP Research Paper 10. Berlin: Stiftung Wissenschaft und Politik German Institute for International and Security Affairs.

Aydın, Y. (2016). Turkish diaspora policy: Transnationalism or long distance natioanlism? Pusch, B. and Sirkeci, İ. (Der.), Turkish Migration Policy içinde (s.169-181). London: Transnational Press.

Bauböck, R. and Faist, T. (2010). Diaspora and transnationalism: Concepts, theories and methods. Amsterdam: Amsterdam University Press.

Bilgili, Ö. and Siegel, M. (2011). Understanding the changing role of the Turkish diaspora. UNU-MERIT Working Papers, No. 039. 
Bundesministerium für Innern, für Bau und Heimat (2018). Verfassungsschutzbericht 2017. 27 Nisan 2020 tarihinde, https://www.verfassungsschutz.de/embed/vsbericht-2017.pdf adresinden erişilmiştir.

Brand, L. A. (2008). Citizens abroad: Emigration and the state in the Middle East and North Africa. New York: Cambridge University Press.

Braziel, J. E. and Mannur, A. (2003). Nation, migration, globalization: Points of contention in diaspora studies. Braziel J. E. and Mannur A. (Der.) Theorizing Diaspora: A Reader içinde (s. 1-22). Oxford: Wiley.

Brown, G. W. (2013). Diaspora, transnationalism and issues in contemporary politics. Daswani, G. and Quaysan A. (Der.) A Companion to Diaspora and Transnationalism içinde (s.68-87). Blackwell: Willey.

Brubaker, R. and Kim, J. (2011). Transborder membership politics in Germany and Korea. European Journal of Sociology, 52 (1), 21-75.

Brubaker, R. (2005): The „diaspora“ diaspora. Ethnic and Racial Studies, 28, 1-19.

Cohen, R. (1997). Global diasporas: An introduction. London: UCL Press.

Das sagte Ministerpräsident Erdogan in Köln (2008, 11 Şubat). Die Welt. [Online gazete haberi]. 29 Mart 2020 tarihinde, https://www.welt.de/debatte/article1660510/Das-sagte-Ministerpraesident-Erdogan-in-Koeln.html adresinden erişilmiştir.

Das weite Netzwerk der AKP in Österreich. (2014, 16 Temmuz). Der Standard [Online gazete haberi,]. 19 Mart 2020 tarihinde, https://derstandard.at/2000002075767/Das-weite-Netzwerk-der-AKP-in-Oesterreich adresinden erişilmiştir.

Dufoix, S. (2011). Diasporalar. İstanbul: Hrant Dink Vakfı Yay.

Eliaçık, Z. (2019). Avusturya. Bayraklı, E., Yalçın, H. B., ve Yeşiltaş, M. (Der.) Avrupa'da PKK yapılanması içinde (s.127-182). İstanbul: SETA Vakfı.

Erşahin, İ. (2015). Bir diyanet projesi olarak uluslararası ilahiyat programı. Diyanet İlmî Dergi, 51(2), 125-146. 28 Mart 2020 tarihinde, http://dergipark.gov.tr/download/article-file/410326 adresinden erişilmiştir.

Gamlen, A., Cummings, M., Vaaler, P. M. ve Rossouw, L. (2013). Explaining the rise of diaspora institutions. The IMI Working Papers Series 78. Oxford: International Migration Institute, University of Oxford. 28 Nisan 2020 tarihinde, $\quad$ http://www.migration.ox.ac.uk/odp/pdfs/WP78\%20Explaining\%20the\%20Rise\%20of\%20Diaspora\%20Institutions.pdf adresinden erişilmiştir. 
Göç Araştırmaları Vakfı. (2018). Bilgi notu: Yurt dışında yaşayan Türk seçmenin siyasal katılımı. 18 Nisan 2020 tarihinde, http://gocvakfi.org/yurt-disindayasayan-turk-secmenin-siyasal-katilimi/ adresinden erişilmiştir.

Glick Schiller, N. Basch, L. ve Szanton Blanc, C. (1992). Towards a transnational perspective on migration: Race, class, ethnicity, and nationalism reconsidered. New York: New York Academy of Sciences.

Hall, S. (1998). “Kültürel kimlik ve diaspora”. J. Rutherford (Der.) Kimlik: topluluk/ kültür/ farklılık içinde (s. 173-192). Ankara: Sarmal Yay.

International Organisation of Migration (2013). Diaspora ministerial conference. 23 Nisan 2020 tarihinde, https://www.iom.int/idmdmc adresinden erişilmiştir.

Itzigsohn, J. (2000). Immigration and the boundaries of citizenship: the institutions of immigrants' political transnationalism. The International Migration Review, 34(4), 1126-1154.

İçduygu, A.; Erder, S. ve Gençkaya, Ö. F. (2014). Türkiye'nin uluslararası göç politikalar 1923-2023: Ulus-devlet oluşumundan ulus-ötesi dönüşümlere. İstanbul: Koç Üniversitesi Göç Araştırmaları Merkezi. 3 Nisan 2020 tarihinde, http://mirekoc.ku.edu.tr/sites/mirekoc.ku.edu.tr/files/T\%C3\%BCbitak\% 20Raporu.pdf adresinden erişilmiştir.

Joppke, C. (2003). Citizenship between de- and re-ethnicization. European Journal of Sociology, 44 (3), 429-458.

Kaya, A. ve Kentel, F. (2005). Euro-Türkler Türkiye ile Avrupa Birliği arasında köprü mü, engel mi? İstanbul: İstanbul Bilgi Üniversitesi Yay.

Kaya, A. (2000). Sicher in Kreuzberg: Berlin'deki küçük İstanbul: Diyasporada kimliğ̈in oluşumu. İstanbul: Büke Yay.

Keskin, K. (2017). Türkiye'nin dış Türkler siyasetinin dönüşümü. İnat, K., Aslan, A. ve Duran, B. (Der.) AK Parti'nin 15 yılı: Dış politika içinde (s. 531-551). İstanbul: SETA Vakfi.

Kurubaş, E. (2006). Asimilasyondan tanımmaya: Uluslararası alanda azınlık sorunları ve Avrupa yaklaşımı (2. baskı). Ankara: Asil Yay.

Kuznetsov, Y. and Sabel, C. (2006). Global mobility of talent from a perspective of new industrial policy: Open migration chains and diaspora networks. WIDER Working Paper Series 144, World Institute for Development Economic Research. 13 Mart 2020 tarihinde, https://www.researchgate.net/publication/23547741 Global Mobility of Talent from a Perspective of New Industrial Policy Open Migration Chains and Diaspora Networks adresinden erişilmiştir. 
Larner, W. (2007). Expatriate experts and globalising governmentalities: The New Zealand diaspora strategy. Transactions of the Institute of British Geographers, 32(3), 331-345.

Steinvorth, D. (2019, 29 May1s). Der Moscheeverband DITIB könnte bei der Integration muslimischer Deutscher eine wichtige Rolle spielen. Doch ihr oberster Dienstherr in Ankara hat andere Prioritäten. Neue Zürcher Zeitung. 9 Nisan 2020 tarihinde, https://www.nzz.ch/meinung/moscheeverband-ditib-die-parallelgesellschafter-ld.1484926 adresinden erişilmiştir.

Okyay, A. S. (2015). Diaspora-making as a state-led project: Turkey's expansive diaspora strategy and its implications for emigrant and kin populations. Doktora Tezi. Florence: European University Institute.

Østergaard Nielsen, E. (2003). The politics of migrants' transnational political practices. International Migration Review, 37 (3), 760-786.

Öniş, Z. ve Kutlay, M. (2013). Rising powers in a changing global order: the political economy of Turkey in the age of brics. Third World Quarterly, 34 (8), 1409-1426.

Ragazzi, F. (2014). A comparative analysis of diaspora policies. Political Geography, 41, 74-89.

Safran, W. (1991). Diasporas in modern society: Myths of homeland and return. Diaspora: A Journal of Transnational Studies, 1(1), 83-99.

Şimşek, H. (2017). 50 Jahre Migration aus der Türkei nach Österreich. Wien: Lit Verlag.

T.C. Başbakanlık. Yurtdışı Türkler Başkanlığı Teşkilat ve Görevleri Hakkında Kanun Tasarısı. (t.y) 09 Temmuz 2018 tarihinde, http://www.basbakanlik.gov.tr/docs/kkgm/kanuntasarilari/yurtdisiturkleri.doc. adresinden erişilmiştir.

T.C. Milli Eğitim Bakanlığı, Avrupa Birliği ve Dış İlişkiler Genel Müdürlüğü. (t.y.). Yurtdışı Temsilciliklerimiz. 5 Nisan 2020 tarihinde, http://abdigm.meb.gov.tr/www/yurt-disi-temsilciliklerimiz/icerik/27 adresinden erişilmiştir.

The United States Agency for International Development (2013). USAID partnership opportunities: Diaspora. 10 Nisan 2020 tarihinde, http://www.usaid.gov/partnership-opportunities/diaspora-engagement adresinden erişilmiştir.

Tötölyan, K. (1996). Rethinking diaspora(s): Stateless power in the transnational moment. Diaspora: A Journal of Transnational Studies, 5 (1), 3-36. 
Türkiye Büyük Millet Meclisi.(t.y). Melen hükümeti programı. 24 Mart 2020 tarihinde, http://tbmm.gov.tr/hukumetler/HP35.htm adresinden erişilmiştir.

Türkiye Cumhuriyeti Anayasası. (1982). Türkiye Büyük Millet Meclisi. 17 Mart 2020 tarihinde, https://www.tbmm.gov.tr/anayasa/anayasa82.htm adresinden erişilmiştir.

Ulusoy, E. (2016). Diasporayı yeniden düşünmek: Diaspora teorisi ve tarihsel bağlamda Türkiye'nin diaspora politikası. Ankara: PEGEM Akademi.

Unat, K. (2017, 9 Ağustos). Türk-Alman İlişkilerini Anlamak V: Diaspora ve Lobi. SETA Vakfi. 02.07.2020 tarihinde, https://www.setav.org/turk-alman-iliskilerini-anlamak-v-diaspora-ve-lobi// adresinden erişilmiştir.

Ünver, C. (2013). Changing diaspora politics of turkey and public diplomacy, Turkish Policy Quarterly, 12 (1), 181-189.

Wahlbeck, Ö. (2002). The concept of diaspora as an analytical tool in the study of refugee communities. Journal of Ethnic and Migration Studies, 28(2), 221238.

Waterbury, M. A. (2010). Bridging the divide: Towards a comparative framework for understanding kin state and migrant-sending state diaspora politics. Bauböck, R. and Faist, T. (Der.) Diaspora and Transnationalism: Concepts, Theories and Methods içinde (s.131-148). Amsterdam: Amsterdam University Press.

Yunus Emre Enstitüsü. (2016). 2016 faaliyet raporu. 9 Nisan 2020 tarihinde, https://www.yee.org.tr/sites/default/files/yayin/2016 faaliyet raporu 05.02.2018-db.pdf adresinden erişilmiştir.

Yeneroğlu, M. (2016). Diaspora politikalarının mikro alana yansıması. Avrupa Türk Gazetesi. 9 Mart 2020 tarihinde, http://www.avrupaturkgazetesi.com/diaspora-politikalarinin-mikro-alana-yansimasi/ adresinden erişilmiştir.

Yurtdışı Türkler ve Akraba Topluluklar Başkanlığı/ YTB. (2016). İdari faaliyet raporu-2016. 11 Nisan 2020 tarihinde, https://www.ytb.gov.tr/uploads/resimler/activity reports/2016-idare-faaliyet-raporu.pdf adresinden erişilmiştir.

Yurtdışı Türkler ve Akraba Topluluklar Başkanlığ1/ YTB. (2017). İdari faaliyet raporu-2017. 11 Nisan 2020 tarihinde, https://www.ytb.gov.tr/uploads/documents/2017 FAAL YET RAPORU Digital.pdf adresinden erişilmiştir. 
Zentürk, A. (Mülakat yapan) ve Bozdağ, B. (Mülakat yapılan).(2012). Bizim için önce insan gelir: Bekir Bozdağ ile söyleşi. [Mülakat transkipsiyonu] Artı 90(1), 4-7. 19 Nisan 2020 tarihinde, https:/www.ytb.gov.tr/uploads/resimler/dergiler pdf/arti-01.pdf adresinden erişilmiştir.

\section{Kaynakça Bilgisi / Citation Information}

Sağlam, E. (2020). Diaspora politikalarına yönelik çağdaş kuramsal yaklaşımlar ve Türk diaspora politikası. OPUS-Uluslararası Toplum Araştırmaları Dergisi, 16(27), 744-774. DOI: 10.26466/opus.747426 